\title{
Mantle Potential Temperature Estimates of Basalt from the East Taiwan Ophiolite
}

\author{
J. Gregory Shellnutt* and Robert B.-J. Hsieh \\ Department of Earth Sciences, National Taiwan Normal University, Taipei City, Taiwan, R.O.C.
}

Received 9 March 2016, revised 15 May 2016, accepted 24 May 2016

\begin{abstract}
The East Taiwan Ophiolite (ETO) is a fragment of the eastern-most South China Sea that was accreted to the Eurasian margin during the Pliocene and is a member of the Western Pacific and Cordilleran belt ophiolite group. Ophiolites from the Western Pacific and Cordilleran belt are typically subduction-related (i.e., supra-subduction or volcanic-arc) but the ETO is compositionally, isotopically and mineralogically similar to subduction-unrelated ophiolites. The primary melt compositions of ETO basaltic rocks were calculated and range from high-Mg basalt to picrite (i.e., $\mathrm{MgO}=10$ to $14 \mathrm{wt} \%$ ). The mantle potential temperature $\left(T_{\mathrm{P}}\right)$ estimates are within the range of ambient mantle $\left(1300-1400^{\circ} \mathrm{C}\right)$ and other mid-ocean ridge ophiolites (i.e., Macquarie Island and Masirah) indicating that it is consistent with a mid-ocean ridge setting. Mantle potential temperature estimates for rocks from a mantle-plume-type ophiolite (i.e., $1620-1630^{\circ} \mathrm{C}$ ) are anomalously high whereas rocks from supra-subduction zone ophiolites show a wider range that extends from ambient (i.e., Troodos and Semail) $T_{\mathrm{P}}$ to very high (i.e., Betts Cove and Bay of Islands) $T_{\mathrm{P}}$.
\end{abstract}

Key words: Ophiolite, Taiwan, South China Sea, Mantle potential temperature

Citation: Shellnutt, J. G. and R. B.-J. Hsieh, 2016: Mantle potential temperature estimates of basalt from the East Taiwan Ophiolite. Terr. Atmos. Ocean. Sci., 27, 853-863, doi: 10.3319/TAO.2016.05.24.01(TT)

\section{INTRODUCTION}

Ophiolites are the remnants of ancient oceanic crust and upper mantle that were tectonically emplaced into continental margins (Penrose 1972; Coleman 1977; Nicolas 1989; Dilek 2003). They can be divided into two major groups: (1) subduction-unrelated and (2) subduction-related (Dilek and Furnes 2011, 2014). The subduction-unrelated group includes ophiolites derived from mid-ocean ridges (MOR), continental margins, and mantle-plumes whereas the subduction-related group includes the supra-subduction zone (SSZ) and volcanic-arc types (Dilek and Furnes 2011, 2014).

Ophiolites occur within five major orogenic systems: the Indonesian belt, Western Pacific and Cordilleran belt (WPCB), Alpine-Himalaya belt, Appalachian-CaledonianHercynian-Uralian-Central Asian belt, and the Tasmanides (Dilek and Furnes 2011, 2014). The WPCB extends along a great circle for more than $25000 \mathrm{~km}$ around the Pacific Ocean rim and includes the western Pacific islands (e.g., Japan, Ryukyu islands, Taiwan, Philippines, Indonesia, Pap-

\footnotetext{
* Corresponding author

E-mail:jgshelln@ntnu.edu.tw
}

ua New Guinea, eastern Australia, and New Zealand) and the Cordilleran belts of western North and South America (Ishiwatari 1991, 1994; Dilek 2003; Dilek and Furnes 2011, 2014; Furnes et al. 2014). The WPCB ophiolites (e.g., Josephine, Trinity, Smartville, Itogon, Papua New Guinea, Zambales, and Yakuno) typically show geochemical and structural characteristics of SSZ or volcanic-arc ophiolites and are found mostly on or among the accreted oceanic and trench sediments of active continental margins (Ishiwatari 1994; Dilek 2003; Dilek and Polat 2008; Dilek and Furnes 2011, 2014). The middle Miocene ( 14 Ma) East Taiwan Ophiolite (ETO) is unusual amongst the WPCB ophiolites as it represents a highly depleted mantle composition that differs from the SSZ-type or volcanic arc-type ophiolites (Jahn 1986; Chung and Sun 1992; Shao 2015; Hsieh et al. 2016).

Although all interpretations recognize the oceanic nature of the ETO rock suite, the precise origin is debated (Suppe et al. 1981; Jahn 1986; Chung and Sun 1992; Shao 2015). Early interpretations suggest the ETO was a submarine scree deposit consisting of angular mafic and ultramafic plutonic blocks that formed at a 'leaky' transform fault 
offsetting (Liou et al. 1977; Suppe et al. 1981). Jahn (1986), Chung and Sun (1992), and Hsieh et al. (2016), based on basalt geochemistry and $\mathrm{Cr}$-spinel data from the peridotites, suggested that the ETO is likely representative of a midoceanic ridge. The nature of the ETO has direct implications on understanding the growth and development of the South China Sea (Taylor and Hayes 1980; Lee and Lawver 1995; Barckhausen and Roeser 2004; Barckhausen et al. 2014, 2015; Li et al. 2014; Chang et al. 2015).

The ETO thermal regime has not been estimated before, thus it is uncertain if the conditions were anomalously high or typical of ambient mantle. The primary melt composition and mantle potential temperature of basalt from different tectonic settings (i.e., ocean-islands, MOR, flood basalt provinces) can be deduced from its bulk composition providing it has only experienced olivine loss (Herzberg et al. 2007; Herzberg and Asimow 2008, 2015). Based on forward modeling of dry peridotite, the primary melt composition can constrain the mantle potential temperature $\left(T_{\mathrm{P}}\right)$ required to produce the melt (Herzberg et al. 2007; Herzberg and Asimow 2008). Mantle potential temperatures at oceanic spreading centers typically range from $1300-1400^{\circ} \mathrm{C}$ whereas some oceanic hotspots and continental flood basalts can be $200-300^{\circ} \mathrm{C}$ above ambient temperatures (Herzberg and Asimow 2008; Ali et al. 2010). The higher mantle potential temperatures at within-plate settings are thought to be an artifact of a mantle-plume (Herzberg et al. 2007; Ali et al. 2010). Thus, mantle potential temperature esti- mates for basaltic rocks from different types of ophiolites (i.e., MOR, SSZ, and plume) may show differences in their thermal regimes. For example, basalt from MOR-type ophiolites should have lower mantle potential temperatures than basalt from mantle-plume-type ophiolites.

In this paper, using PRIMELT3 software, we estimate the primary melt compositions and mantle potential temperatures of basaltic rocks from the ETO in order to determine the likely thermal conditions (Herzberg and Asimow 2015). Moreover, we compare the results to estimates from rocks related to MOR-, plume-, and SSZ-type ophiolites so that the tectonic setting of the ETO can be further constrained.

\section{GEOLOGICAL BACKGROUND}

Taiwan is situated at the junction between the Ryukyuarc and the Luzon-arc and consists of accretionary wedge rocks, island arc rocks and older continental and oceanic lithosphere (Fig. 1) (Chai 1972; Bowin et al. 1978; Suppe 1984; Tsai 1986; Kao et al. 1998). Westward subduction of the Pacific plate beneath the Eurasia plate during the Mesozoic Era ( 150 Ma) was responsible for the Zhejiang-Fujian magmatic arc and the formation of proto-Taiwan. The changing nature of convergence (i.e., slowing subduction and slab roll back) between the paleo-Pacific plate and Eurasia during the Cenozoic allowed for fore-arc sediment accumulation as the Philippine Sea plate rotated clockwise in a northwestward direction (Lee and Lawver 1995). During the middle to late
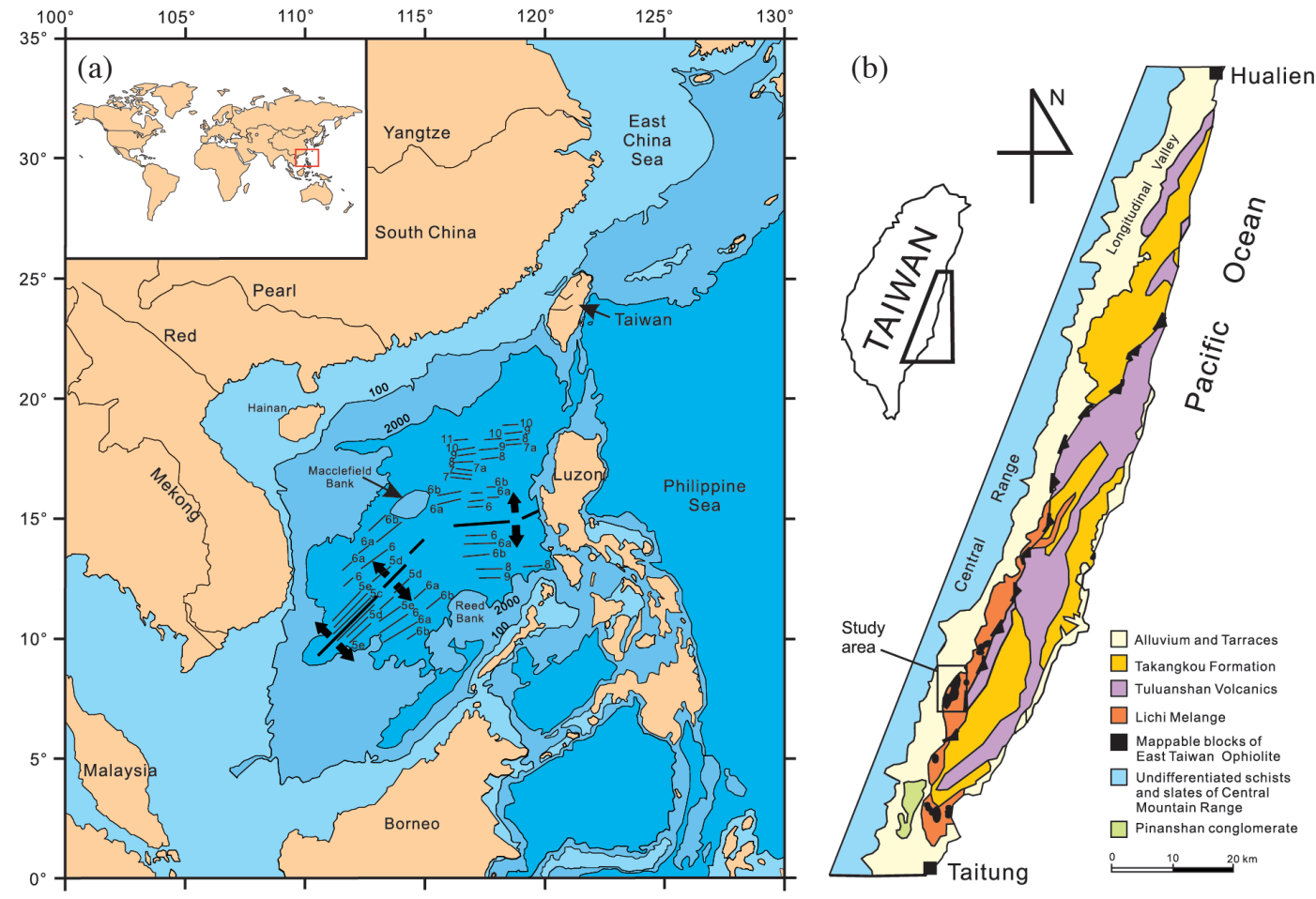

Fig. 1. (a) Regional map of the South China Sea and SE Asia showing the magnetic anomalies of Taylor and Hayes (1983) and Briais et al. (1993). (b) Location of the East Taiwan Ophiolite and simplified geology of the Coastal Range, Taiwan (modified from Liou 1979). 
Miocene ( 15 - $12 \mathrm{Ma})$, the Luzon-arc shifted towards the Eurasian continental shelf along a left-lateral transform fault system in the east and subduction zone system in the north (Teng 1990; Huang et al. 2006). The obduction between the Luzon-arc and Eurasian continental shelf induced uplift of accretionary wedge sediments and formed the proto-Central Mountain Range of Taiwan during the mid to late Pliocene (Teng 1990; Huang et al. 2006). By the late Pliocene, the northern Luzon-arc collided obliquely with Eurasia and reached its current position. The volcanic rocks of the Luzonarc accreted into the uplifted Pliocene-Pleistocene passive margin sediments of Eurasia and became the Coastal Range whereas the uplifted sedimentary rocks developed into the Central Range. At the same time as the Luzon-Eurasia collision, the tectonic stress in northeast Taiwan transformed from compression to extension as the Philippine Sea plate continued to subduct beneath the Ryukyu-arc that induced back-arc extension and the opening of the Okinawa Trough and Yilan basin (Suppe 1984; Lee and Wang 1987; Teng 1990, 1996, 2007; Kao et al. 1998).

The ETO is within the Lichi mélange of the Coastal Range and consists of large blocks and boulders of fossiliferous sea-floor sediments, pillow basalt with glassy margins, mafic dykes, plagiogranite, gabbro, pegmatite, and serpentinized peridotite (Liou et al. 1977; Liou 1979; Liou and Ernst 1979; Suppe and Liou 1979; Page and Suppe 1981; Suppe et al. 1981; Jahn 1986; Chung and Sun 1992). The idealized stratigraphy of the ETO is shown in Fig. 2 and is based on the work by Liou et al. (1977). The lower brecciated sequence consists of plutonic (i.e., gabbros, diabase, plagiogranite) rocks and serpentinized peridotite and is con- tact with the Lichi mélange. Thin layers (i.e., $10-50 \mathrm{~cm}$ ) of red shale and siltstone are found at the top of the plutonic rocks followed by the extrusive sequence of massive flows, pillow basalt with glassy rims and pillow breccia. Layers of red shale are reported between some volcanic units. Radioisotope dating (i.e., $\mathrm{U} / \mathrm{Pb}$ and $\mathrm{Ar} / \mathrm{Ar}$ ) of the ETO yielded results between $17.5 \pm 0.2$ and $14.1 \pm 0.2 \mathrm{Ma}$ (Jahn 1986; Shao 2015; Hsieh et al. 2016). The whole rock geochemistry of the ETO basalts show depleted light-rare earth element patterns, N-MORB-like (normal-mid-ocean ridge basalt) whole rock compositions and $\mathrm{Sr}-\mathrm{Nd}$ isotopic characteristics of depleted mantle (Jahn 1986; Yui and Yang 1988). Furthermore, the Cr-spinels from the ETO peridotites are compositionally similar to spinels from peridotites dredged from MOR (Dick and Bullen 1984; Hsieh et al. 2016).

\section{PRIMELT3 CALCULATIONS}

Primary melt compositions and mantle potential temperature estimates $\left(T_{\mathrm{P}}\right)$ were calculated for basaltic rocks from the ETO and ophiolites that are classified as MORtype (i.e., Macquarie Island, SW Pacific and Masirah, Oman), mantle-plume-type (i.e., Mino-Tamba, SW Japan), and supra-subduction-type (i.e., Semail, Oman; Troodos, Cyprus; Bay of Islands and Betts Cove, Canada).

Basalts with $\mathrm{Mg} \# \geq 65$ from the ETO and MOR were selected for modeling whereas basalts from other settings were not restricted but generally had Mg\# $>60$. The selection criteria for the ETO and MOR ophiolites were relatively strict because primitive MORB typically has $\mathrm{Mg} \# \geq 65$ (Kamenetsky et al. 2000). Other modeling parameters such

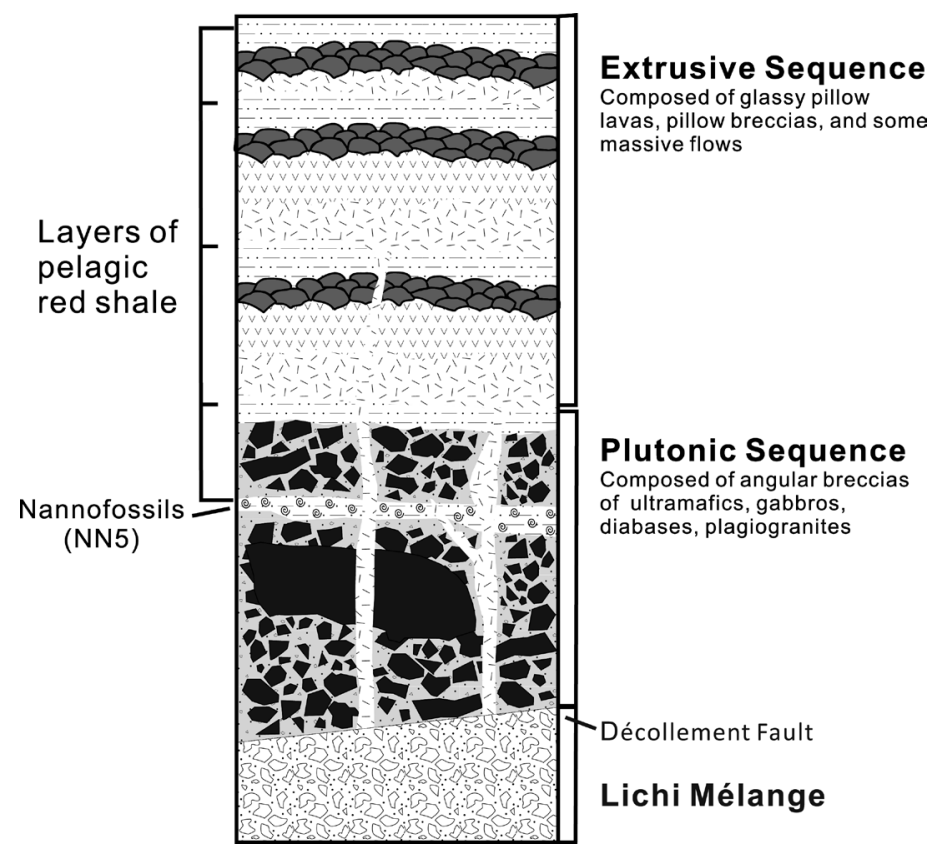

Fig. 2. Idealized stratigraphy of the ETO based on Liou et al. (1977). 
as source composition and relative oxidation state were adjusted based on the type of ophiolite. For example, the FeOt content of mantle peridotite generally ranges between 8.0 and $9.0 \mathrm{wt} \%$ and the relative oxidation state of the mantle at MOR and mantle-plume settings tend to be more reducing relative to volcanic-arc-related settings (Herzberg and O'Hara 2002; Bézos and Humler 2005; Cottrell and Kelley 2011; Kelley and Cottrell 2012). We selected the lowest $\mathrm{FeOt}$ mantle value that produced a meaningful result whereas $\mathrm{MgO}$ was fixed to $38.12 \mathrm{wt} \%$. In order to compensate for the differences in the relative oxidation state between volcanic-arc-unrelated and volcanic-arc-related ophiolites we set the $\mathrm{Fe}_{2} \mathrm{O}_{3} / \mathrm{TiO}_{2}=0.5$ (i.e., reducing) for the ETO, Macquarie Island and Masirah whereas the remaining ophiolites are modeled with an $\mathrm{Fe}_{2} \mathrm{O}_{3} / \mathrm{TiO}_{2}=1.0$ (Herzberg and Asimow 2008, 2015).

The accumulated fractional melt (AFM) results from PRIMELT3 are plotted on a series of FeOt vs. $\mathrm{MgO}$ diagrams that show the primary melt composition and the equilibrium melting olivine control line (Figs. 3 and 4). The AFM composition represents the accumulation of melt fractions over the duration of source melting and is probably more representative of the processes that generate melts from the mantle (Herzberg and Asimow 2008). The solidus, melt fraction, and pressure lines shown in the models are derived from Herzberg and O'Hara (2002), Herzberg et al. (2007), and Herzberg and Asimow (2008, 2015). The ETO and MOR ophiolite results are plotted relative to the depleted mantle equilibrium melting curves due to their interpretation as mid-ocean spreading centers whereas the others are plotted relative to fertile peridotite melting curves due to their association with either a mantle plume or subduction zone systems. Pressure estimates for depleted mantle melting are not provided due to limited experimental data (Herzberg and O'Hara 2002). The complete primary melt compositions and temperature estimates are listed in the online supplementary Table S1.

\section{PRIMARY MELT COMPOSITIONS AND MANTLE POTENTIAL TEMPERATURE ESTIMATES}

The primary melt compositions and olivine control lines for ETO basaltic rocks are shown in Fig. 3 and listed in Table 1 . The calculations indicate the primary magmas are picritic to high- $\mathrm{Mg}$ basalt $(\mathrm{MgO}=9.9$ to $13.4 \mathrm{wt} \%)$ that experienced $\sim 3$ to $\sim 6 \%$ olivine loss (Le Bas et al. 2000). The calculated initial olivine had forsterite values between 89 and 91 (Fig. 3b). The eruptive temperatures (T) and mantle potential temperatures $\left(T_{\mathrm{P}}\right)$ are estimated to be $1220-1310^{\circ} \mathrm{C}$ and $1300-1390^{\circ} \mathrm{C}$ respectively.

The melt compositions and $T_{\mathrm{P}}$ for basaltic glass from the Macquarie Island ophiolite and rocks from the Masirah ophiolite show the primary magmas of both ophiolites were picritic to high-Mg basalt $(\mathrm{MgO}=10.8$ to $13.4 \mathrm{wt} \%)$ (Fig. 3c). The Masirah primary melt composition experienced $8-12 \%$ olivine loss and the Macquarie Island melt experienced $7-11 \%$ loss. The $T_{\mathrm{P}}$ of the Masirah ophiolite ranges from $1320-1400^{\circ} \mathrm{C}$ whereas the Macquarie Island ophiolite ranges from $1340-1390^{\circ} \mathrm{C}$ (Table 2).

The primary melt compositions of rocks from the MinoTamba belt are shown in Fig. 4a. The calculations indicate the melt compositions are picritic $\left(\mathrm{MgO}=22 \mathrm{wt} \%, \mathrm{Na}_{2} \mathrm{O}+\right.$ $\mathrm{K}_{2} \mathrm{O}>1 \mathrm{wt} \%$ ) and experienced $\sim 22 \%$ olivine loss from a garnet peridotite. The estimated eruptive temperatures $(\mathrm{T})$ and mantle potential temperatures $\left(T_{\mathrm{P}}\right)$ are $1475-1490^{\circ} \mathrm{C}$ and $1620-1630^{\circ} \mathrm{C}$ (Table 2).

The rocks from supra-subduction-zone ophiolites produced high- $\mathrm{Mg}$ basalt to picritic $(\mathrm{MgO}=10.9$ to $17.1 \mathrm{wt} \%)$ primary melts (Fig. 4b). The estimated eruptive and mantle potential temperatures of the Troodos (upper pillow sequence at the Kythreotis quarry) and Semail (Lower extrusive Geotimes unit) ophiolites are $1250-1330^{\circ} \mathrm{C}$ and $1325-1420^{\circ} \mathrm{C}$. In comparison the Bay of Islands and Betts Cove ophiolites have higher estimated eruptive and mantle potential temperatures of $1320-1390^{\circ} \mathrm{C}$ and $1410-1490^{\circ} \mathrm{C}$ (Table 2).

\section{DISCUSSION}

The calculated primary melt compositions of the ETO basaltic rocks suggest that the thermal regime of the ETO mantle was not anomalously hot (i.e., $>1550^{\circ} \mathrm{C}$ ) and that it was similar to ambient mantle (Fig. 5). It seems that many of the ETO basaltic rocks are very close to primary melts as the model predicts $\leq 6 \%$ olivine loss and initial olivine compositions with Mg\# 89 to 91 (Fig. 3b). The reported Mg\# from ETO gabbro, mafic dykes, and basalt are between 83 and 87 with $\mathrm{Mg} \#$ of 87 to 91 for ETO peridotites (Liou et al. 1977). In comparison, the $T_{\mathrm{P}}$ estimates of mafic rocks from MOR-type ophiolites (i.e., Macquarie Island and Masirah) are indistinguishable from the ETO (Fig. 5).

An examination of the mantle potential temperatures of plume-type and SSZ-type ophiolites reveals that there are, in general, differences between the thermal regimes of MOR-type ophiolites and other types (Fig. 5). The calculated mantle potential temperatures from the Mino-Tamba plume-type ophiolite from SW Japan are very high (i.e., $>1550^{\circ} \mathrm{C}$ ) and supportive of a hot mantle regime expected from a mantle-plume setting (Herzberg and Asimow 2008, 2015). The presence of ultramafic volcanic rocks within the Mino-Tamba belt is consistent with the expectation of a mantle-plume derived large igneous province (Campbell 2007; Ali et al. 2010).

The $T_{\mathrm{P}}$ estimates for the SSZ ophiolites clearly indicate that the Troodos and Semail ophiolites have $T_{\mathrm{P}}$ (i.e., 1325 and $1420^{\circ} \mathrm{C}$ ) similar to ambient mantle whereas the Betts Cove and Bay of Islands ophiolites have higher thermal conditions (i.e., $1410-1490^{\circ} \mathrm{C}$ ). It is uncertain why there 
(a)

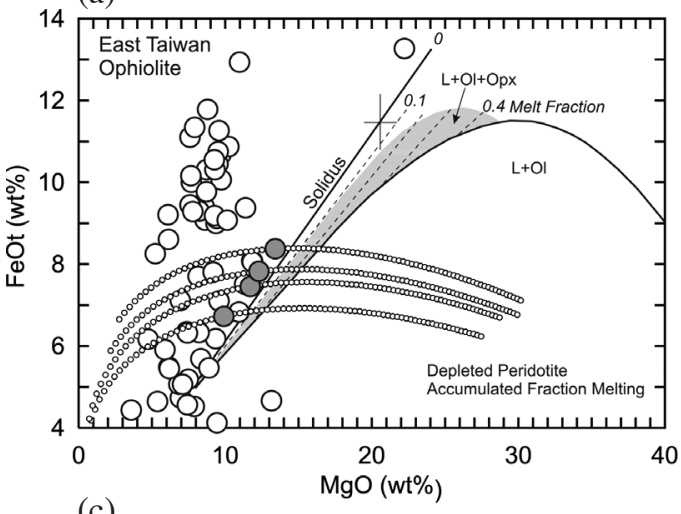

(b)

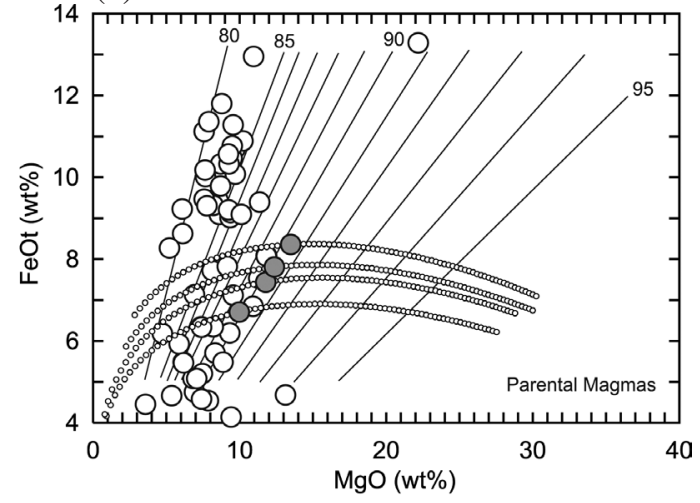

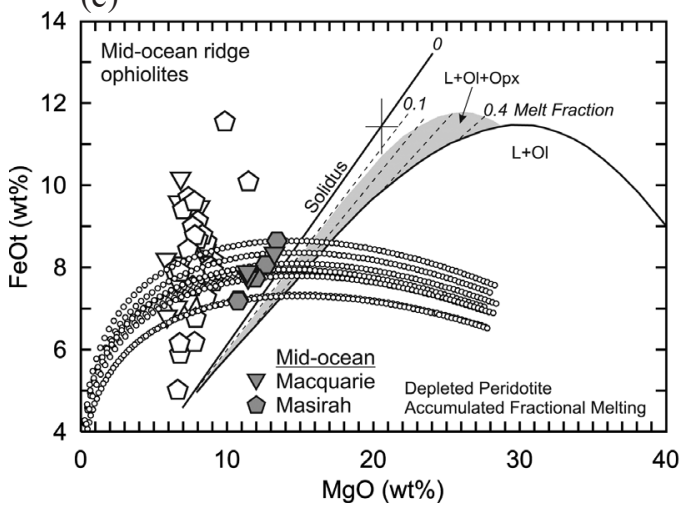

Fig. 3. (a) FeOt vs. $\mathrm{MgO}$ of calculated primary melt compositions and basaltic rock chemistry for the ETO. The primary melt composition (solid circles) calculation results using PRIMELT3 (Herzberg and Asimow 2015). The small white circles represent the olivine control lines generated by the addition or subtraction of calculated equilibrium olivine compositions for ETO basaltic rocks. Dashed lines are melt fraction contours and the crosses indicate uncertainties in calculated $\mathrm{FeO}$ and $\mathrm{MgO}$ content related to $\pm 1 \sigma \mathrm{K}_{\mathrm{D}}^{\mathrm{O} / \mathrm{L}} \mathrm{FeO} / \mathrm{MgO}$. The ETO basalt data (open circles) are from Juan et al. (1976, 1980), Liou et al. (1977), Chou et al. (1978), Suppe et al. (1981), and Jahn (1986). (b) The primary melt compositions are plotted relative to the equilibrium olivine composition. The numbers (i.e., 80, 85, 90, and 95) represent $\mathrm{Mg \#} \mathrm{(forsterite} \mathrm{content)} \mathrm{of} \mathrm{olivine.} \mathrm{(c)} \mathrm{FeOt} \mathrm{vs.} \mathrm{MgO}$ of calculated primary melt compositions and basaltic rock chemistry of mid-ocean ridge ophiolites (i.e., Macquarie Island and Masirah). The Macquarie Island and Masirah basalt data (open inverted triangles and hexagons) from Peters and Mercolli (1998), Kamenetsky et al. (2000).

(a)

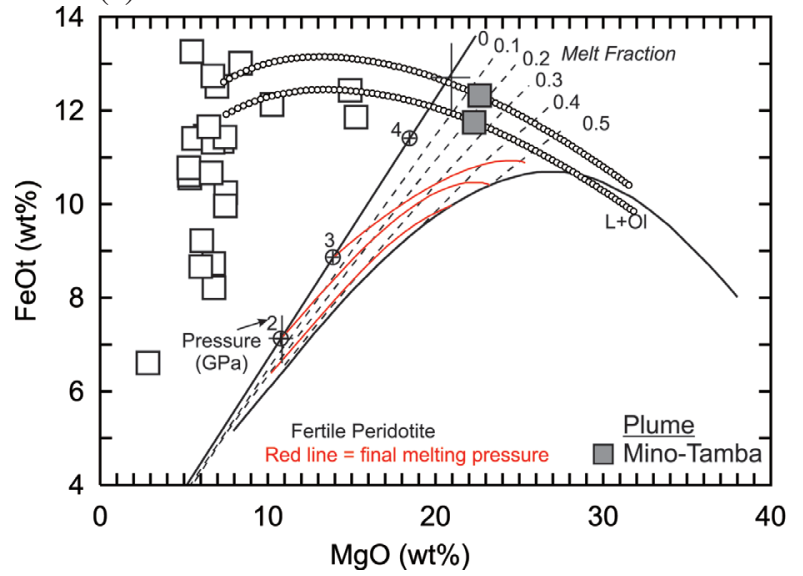

(b)

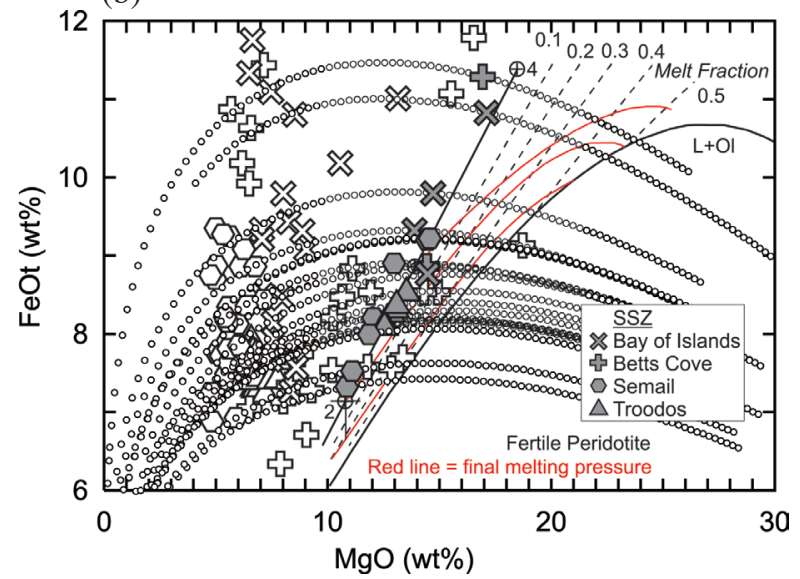

Fig. 4. FeOt vs. $\mathrm{MgO}$ of calculated primary melt compositions and basaltic rock chemistry of (a) mantle-plume type ophiolite (i.e., Mino-Tamba) and (b) supra-subduction zone ophiolites (i.e., Troodos, Semail, Bay of Islands and Betts Cove). The classification of each ophiolite is based on the criteria outline in Dilek and Furnes (2011). The small white circles represent the olivine control lines generated by the addition or subtraction of calculated equilibrium olivine compositions. Dashed lines are melt-fraction contours and the red lines represent final melting pressure. The data are from Coish (1977), Coish et al. (1982), Karson et al. (1983), Thy and Xenophontos (1991), Einaudi et al. (2003), Kurth-Velz et al. (2004), Ichiyama et al. (2008, 2014), and MacLeod et al. (2013). 
Table 1. Primary melt compositions and mantle potential temperature estimates of the East Taiwan Ophiolite basalt.

\begin{tabular}{|c|c|c|c|c|c|c|c|c|}
\hline Sample & F36 & AFM & T94A & AFM & T226A & AFM & T238A & AFM \\
\hline $\mathrm{SiO}_{2}(\mathrm{wt} \%)$ & 50.0 & 50.32 & 50.77 & 51.40 & 48.34 & 49.52 & 49.34 & 50.74 \\
\hline $\mathrm{TiO}_{2}$ & 0.54 & 0.52 & 0.51 & 0.50 & 0.86 & 0.86 & 0.74 & 0.75 \\
\hline $\mathrm{Al}_{2} \mathrm{O}_{3}$ & 16.3 & 15.62 & 15.97 & 15.52 & 13.75 & 13.69 & 13.49 & 13.67 \\
\hline $\mathrm{Fe}_{2} \mathrm{O}_{3}$ & 0.72 & 0.26 & 7.92 & 0.25 & 8.98 & 0.43 & 8.38 & 0.38 \\
\hline $\mathrm{FeO}$ & 5.70 & 6.49 & & 7.23 & & 7.93 & & 7.48 \\
\hline \multicolumn{9}{|l|}{$\mathrm{FeOt}$} \\
\hline $\mathrm{MnO}$ & 0.14 & 0.15 & 0.16 & 0.17 & 0.13 & 0.13 & 0.10 & 0.10 \\
\hline $\mathrm{MgO}$ & 7.38 & 9.93 & 9.54 & 11.74 & 11.81 & 13.44 & 11.29 & 12.34 \\
\hline $\mathrm{CaO}$ & 14.82 & 14.21 & 11.30 & 11.00 & 11.71 & 11.67 & 12.04 & 12.21 \\
\hline $\mathrm{Na}_{2} \mathrm{O}$ & 2.02 & 1.94 & 2.23 & 2.17 & 2.19 & 2.18 & 2.22 & 2.25 \\
\hline $\mathrm{K}_{2} \mathrm{O}$ & 0.59 & 0.57 & 0.04 & 0.04 & 0.10 & 0.10 & 0.08 & 0.08 \\
\hline \multicolumn{9}{|l|}{$\mathrm{P}_{2} \mathrm{O}_{5}$} \\
\hline LOI & 1.45 & & 1.25 & & 1.52 & & 1.68 & \\
\hline Pressure (bars) & & 1 & & 1 & & 1 & & 1 \\
\hline $\mathrm{FeO}$ (source) & & 8.02 & & 8.28 & & 8.13 & & 8.16 \\
\hline $\mathrm{MgO}$ (source) & & 38.12 & & 38.12 & & 38.12 & & 38.12 \\
\hline $\mathrm{Fe}_{2} \mathrm{O}_{3} / \mathrm{TiO}_{2}$ & & 0.5 & & 0.5 & & 0.5 & & 0.5 \\
\hline$\%$ ol addition & & 6.2 & & 5.3 & & 3.5 & & 1.8 \\
\hline Temperature $\left({ }^{\circ} \mathrm{C}\right)$ & & 1220 & & 1270 & & 1310 & & 1280 \\
\hline$T_{\mathrm{P}}\left({ }^{\circ} \mathrm{C}\right)$ & & 1300 & & 1350 & & 1390 & & 1365 \\
\hline
\end{tabular}

Note: $\mathrm{AFM}=$ accumulated fractional melt. $\mathrm{FeOt}=\mathrm{Fe}_{2} \mathrm{O}_{3} \mathrm{t} \times 0.8998$. The model compositions are normalized to $100 \%$ for the PRIMELT3 calculation. Data from Liou et al. (1977), Juan et al.(1980), and Suppe et al.(1981).

Table 2. Summary of mantle potential temperatures, and eruption temperatures and $\mathrm{MgO}$ content of primary melt compositions of basalts from different ophiolites.

\begin{tabular}{|c|c|c|c|c|c|c|c|}
\hline Ophiolite & Location & Sample & Material & $\operatorname{MgO}(w t \%)$ & $\mathbf{T}\left({ }^{\circ} \mathbf{C}\right)$ & $T_{\mathrm{P}}\left({ }^{\circ} \mathrm{C}\right)$ & Reference \\
\hline \multirow{8}{*}{ MOR } & \multirow{3}{*}{ Macquarie Island } & 47979 & \multirow{3}{*}{ glass } & 13.3 & 1305 & 1390 & \multirow[t]{3}{*}{ Kamenetsky et al. (2000) } \\
\hline & & 25637 & & 11.5 & 1270 & 1340 & \\
\hline & & G855 & & 11.4 & 1280 & 1340 & \\
\hline & \multirow{5}{*}{ Masirah } & J149 & \multirow{5}{*}{ rock } & 12.7 & 1300 & 1370 & \multirow[t]{5}{*}{ Peters and Mercolli (1998) } \\
\hline & & $\mathrm{J} 238$ & & 10.8 & 1250 & 1320 & \\
\hline & & P017 & & 13.4 & 1310 & 1400 & \\
\hline & & P018 & & 10.8 & 1260 & 1320 & \\
\hline & & P026 & & 12.0 & 1280 & 1360 & \\
\hline \multirow{7}{*}{ SSZ } & \multirow{7}{*}{ Semail } & $13-87$ & \multirow{7}{*}{ rock } & 12.1 & 1300 & 1360 & \multirow[t]{2}{*}{ Einaudi et al. (2003) } \\
\hline & & $24-169$ & & 13.0 & 1320 & 1380 & \\
\hline & & $990 \mathrm{OC} 118$ & & 10.9 & 1260 & 1325 & MacLeod et al. (2013) \\
\hline & & $890 C 007$ & & 11.9 & 1260 & 1360 & \\
\hline & & $890 C 023$ & & 11.1 & 1250 & 1330 & \\
\hline & & OM146 & & 14.4 & 1330 & 1420 & \\
\hline & & OM147 & & 14.6 & 1330 & 1420 & \\
\hline
\end{tabular}

Note $: M O R=$ mid-ocean ridge, $S S Z=$ suprasubduction zone $;$ PLUM = mantle-plume . 
Table 2. (Continued)

\begin{tabular}{|c|c|c|c|c|c|c|c|}
\hline Ophiolite & Location & Sample & Material & $\operatorname{MgO}(w t \%)$ & $\mathbf{T}\left({ }^{\circ} \mathbf{C}\right)$ & $T_{\mathrm{P}}\left({ }^{\circ} \mathrm{C}\right)$ & Reference \\
\hline \multirow{14}{*}{ SSZ } & \multirow{7}{*}{ Troodos } & KY1 & \multirow{7}{*}{ glass } & 12.6 & 1290 & 1370 & \multirow[t]{7}{*}{ Thy and Xenophontos (1991) } \\
\hline & & KY2 & & 12.9 & 1290 & 1380 & \\
\hline & & KY3b & & 13.4 & 1300 & 1390 & \\
\hline & & KY4 & & 12.6 & 1290 & 1370 & \\
\hline & & KY6b & & 13.5 & 1310 & 1400 & \\
\hline & & KY6p & & 12.6 & 1285 & 1370 & \\
\hline & & KY7h & & 13.1 & 1300 & 1380 & \\
\hline & \multirow{3}{*}{ Betts Cove } & BC-74-58 & \multirow{3}{*}{ rock } & 14.5 & 1330 & 1420 & \multirow{3}{*}{$\begin{array}{c}\text { Coish (1977) } \\
\text { Coish et al. (1982) }\end{array}$} \\
\hline & & BC-75-8 & & 16.9 & 1390 & 1485 & \\
\hline & & $7458 \mathrm{~b}$ & & 14.4 & 1330 & 1420 & \\
\hline & \multirow{4}{*}{ Bay of Islands } & LH5600 & \multirow[t]{4}{*}{ rock } & 17.1 & 1380 & 1490 & \multirow{4}{*}{$\begin{array}{l}\text { Karson et al. (1983) } \\
\text { Kurth-Velz et al. (2004) }\end{array}$} \\
\hline & & WL59 & & 13.9 & 1320 & 1410 & \\
\hline & & M40 & & 14.7 & 1350 & 1430 & \\
\hline & & M1169 & & 14.5 & 1330 & 1420 & \\
\hline \multirow{2}{*}{ PLUM } & \multirow{2}{*}{ Mino-Tamba } & 110521-10A & \multirow[t]{2}{*}{ rock } & 22.7 & 1490 & 1630 & \multirow[t]{2}{*}{ Ichiyama et al. (2008) } \\
\hline & & 111120ST6-1 & & 22.4 & 1475 & 1620 & \\
\hline
\end{tabular}

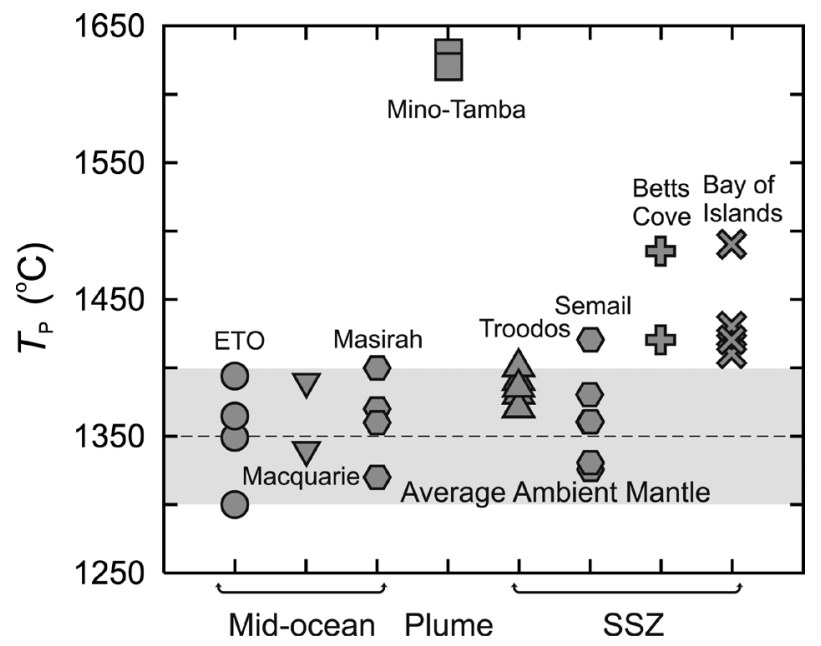

Fig. 5. Estimated mantle potential temperatures $\left(T_{\mathrm{P}}\right)$ of rocks from the ETO, Macquarie Island, Masirah, Mino-Tamba, Troodos, Betts Cove, Semail, and Bay of Islands ophiolites. The average ambient $T_{\mathrm{P}}$ range is from Herzberg and Asimow (2008).

would be a difference between the thermal regimes of the Troodos and Semail ophiolites and the Betts Cove-Bay of Islands ophiolites but it could be related to their specific formation conditions. The Troodos and Semail ophiolites are classic examples of the supra-subduction "Tethyan ophiolites" (Pearce et al. 1984; Searle and Cox 1999; Dilek and Furnes 2011; Whattam and Stern 2011). In both cases the main ophiolite sequences were formed at "subduction initiation centers' (i.e., extension above a subduction zone) and were obducted above the same subduction zone that created them (Stern and Bloomer 1992; Whattam and Stern 2011). In the case of the Early Ordovician Bay of Islands and Betts Cove ophiolites, they likely formed at a fore-arc ridge axis normal to the arc trench trend (Dewey and Casey 2013). In- termediate mantle potential temperature estimates (i.e., 1400 and $1500^{\circ} \mathrm{C}$ ) of basaltic rocks are interpreted to be related to heat incubation beneath moderately thickened crust in the case of some continental large igneous provinces (e.g., Ferrar and Central Atlantic Magmatic Province) or, in the case of some Cenozoic oceanic islands, as evidence of cool, lowmelt-fraction magmas from the periphery of a mantle plume (Coltice et al. 2007; Herzberg and Gazel 2009; Hole 2015). Within the Atlantic Ocean basin there are a number of oceanic islands that are just off the ridge axis (e.g., Azores, Canaries, Tristan da Cunha) and have $T_{\mathrm{P}}$ values between 1400 and $1500^{\circ} \mathrm{C}$. It is therefore possible that a portion of the Bay of Islands and Betts Cove ophiolites may have been influenced by a slightly higher thermal regime of a proximal 
cooling plume (Herzberg and Asimow 2008; Herzberg and Gazel 2009). Alternatively it could be that some basalt from the Bay of Islands and Betts Cove ophiolites formed within slightly thicker oceanic crust as the ridge was intersecting the arc trench. Regardless, in spite of their similar classification as SSZ ophiolites, the thermal regimes of the Troodos and Semail ophiolites and the Bay of Islands and Betts Cove ophiolites appear to be different implying they may represent distinctly different types of SSZ ophiolites.

The similarity in mantle potential temperatures between the ETO and MOR ophiolites, absence of arc-related (i.e., island-arc tholeiites, calc-alkaline basalt, boninite) rocks and the depleted $\mathrm{Nd}$ isotopic composition of peridotite is compelling evidence that the ETO was an open ocean-ridge environment (Jahn 1986; Chung and Sun 1992; Hsieh et al. 2016). The ETO thermal regime is definitively dissimilar to mantle-plume ophiolites and thus it is unlikely that it was associated with that setting. There is overlap between the $T_{\mathrm{P}}$ estimates for the MOR ophiolites and the Troodos and Semail ophiolites suggesting the thermal regime of some SSZtype ophiolites and MOR-type ophiolites are similar.

\section{CONCLUSION}

The results from this study suggest the primary compositions of ETO basalts are similar to high- $\mathrm{Mg}$ basalt to picrite. The mantle potential temperature estimates required to generate the primary melt composition are typical of MOR rather than plume- or some SSZ-type ophiolites. The PRIMELT3 results are additional evidence in support of a MOR interpretation for the ETO.

Acknowledgements We thank the two Anonymous Reviewers for their constructive comments and Kuo-Lung Wang for editorial handling. JGS acknowledges the financial support of the Taiwan Ministry of Science and Technology for its financial support through grant 102-2628-M003-001-MY4.

\section{REFERENCES}

Ali, J. R., J. G. Fitton, and C. Herzberg, 2010: Emeishan large igneous province (SW China) and the mantleplume up-doming hypothesis. J. Geol. Soc., 167, 953959, doi: 10.1144/0016-76492009-129. [Link]

Barckhausen, U. and H. A. Roeser, 2004: Seafloor spreading anomalies in the South China Sea revisited. In: Clift, P., W. Kuhnt, P. Wang, and D. Hayes (Eds.), Continent-Ocean Interactions Within East Asian Marginal Seas, American Geophysical Union, Washington, D. C., 121-125, doi: 10.1029/149GM07. [Link]

Barckhausen, U., M. Engels, D. Franke, S. Ladage, and M. Pubellier, 2014: Evolution of the South China Sea: Revised ages for breakup and seafloor spreading. Mar.
Petrol. Geol., 58, 599-611, doi: 10.1016/j.marpetgeo.2014.02.022. [Link]

Barckhausen, U., M. Engels, D. Franke, S. Ladage, and M. Pubellier, 2015: Reply to Chang et al., 2014, Evolution of the South China Sea: Revised ages for breakup and seafloor spreading. Mar. Petrol. Geol., 59, 679-681, doi: 10.1016/j.marpetgeo.2014.09.002. [Link]

Bézos, A. and E. Humler, 2005: The $\mathrm{Fe}^{3+} / \Sigma \mathrm{Fe}$ ratios of MORB glasses and their implications for mantle melting. Geochim. Cosmochim. Acta, 69, 711-725, doi: 10.1016/j.gca.2004.07.026. [Link]

Bowin, C., R. S. Lu, C. S. Lee, and H. Schouten, 1978: Plate convergence and accretion in Taiwan-Luzon region. AAPG Bull., 62, 1645-1672.

Briais, A., P. Patriat, and P. Tapponnier, 1993: Updated interpretation of magnetic anomalies and seafloor spreading stages in the South China Sea: Implications for the Tertiary tectonics of Southeast Asia. J. Geophys. Res., 98, 6299-6328, doi: 10.1029/92JB02280. [Link]

Campbell,I.H.,2007: Testing the plume theory.Chem.Geol., 241, 153-176, doi: 10.1016/j.chemgeo.2007.01.024. [Link]

Chai, B. H. T., 1972: Structure and tectonic evolution of Taiwan. Am. J. Sci., 272, 389-422, doi: 10.2475/ ajs.272.5.389. [Link]

Chang, J. H., T. Y. Lee, H. H. Hsu, and C. S. Liu, 2015: Comment on Barckhausen et al., 2014 -Evolution of the South China Sea: Revised ages for breakup and seafloor spreading. Mar. Petrol. Geol., 59, 676-678, doi: 10.1016/j.marpetgeo.2014.09.003. [Link]

Chou, C. L., H. J. Lo, J. H. Chen, and V. C. Juan, 1978: Rare earth element and isotopic geochemistry of Kuanshan igneous complex, Taiwan. Proc. Geol. Soc. China, 21, 13-24.

Chung, S. L. and S. Sun, 1992: A new genetic model for the East Taiwan Ophiolite and its implications for Dupal domains in the Northern Hemisphere. Earth Planet. Sci. Lett., 109, 133-145, doi: 10.1016/0012-821X(92)90079-B. [Link]

Coish, R. A., 1977: Ocean floor metamorphism in the Betts Cove ophiolite, Newfoundland. Contrib. Mineral. Petrol., 60, 255-270, doi: 10.1007/BF01166800. [Link]

Coish, R. A., R. Hickey, and F. A. Frey, 1982: Rare earth element geochemistry of the Betts Cove ophiolite, Newfoundland: Complexities in ophiolite formation. Geochim. Cosmochim. Acta, 46, 2117-2134, doi: 10.1016/0016-7037(82)90189-2. [Link]

Coleman, R. G., 1977: Ophiolites, Springer-Verlag, 229 pp.

Coltice, N., B. R. Phillips, H. Bertrand, Y. Ricard, and P. Rey, 2007: Global warming of the mantle at the origin of flood basalts over supercontinents. Geology, 35, 391-394, doi: 10.1130/G23240A.1. [Link]

Cottrell, E. and K. A. Kelley, 2011: The oxidation state of $\mathrm{Fe}$ in MORB glasses and the oxygen fugacity of the 
upper mantle. Earth Planet. Sci. Lett., 305, 270-282, doi: 10.1016/j.eps1.2011.03.014. [Link]

Dewey, J. F. and J. F. Casey, 2013: The sole of an ophiolite: the Ordovician Bay of Islands Complex, Newfoundland. J. Geol. Soc., 170, 715-722, doi: 10.1144/ jgs2013-017. [Link]

Dick, H. J. B. and T. Bullen, 1984: Chromian spinel as a petrogenetic indicator in abyssal and alpine-type peridotites and spatially associated lavas. Contrib.Mineral. Petrol., 86, 54-76, doi: 10.1007/BF00373711. [Link]

Dilek, Y., 2003: Ophiolite pulses, mantle plumes and orogeny. Geol. Soc. Lond. Spec. Publ., 218, 9-19, doi: 10.1144/GSL.SP.2003.218.01.02. [Link]

Dilek, Y. and H. Furnes, 2011: Ophiolite genesis and global tectonics: Geochemical and tectonic fingerprinting of ancient oceanic lithosphere. Geol. Soc. Am. Bull., 123, 387-411, doi: 10.1130/B30446.1. [Link]

Dilek, Y. and H. Furnes, 2014: Ophiolites and their origins. Elements, 10,93-100, doi: 10.2113/gselements.10.2.93. [Link]

Dilek, Y. and A. Polat, 2008: Suprasubduction zone ophiolites and Archean tectonics. Geology, 36, 431-432, doi: 10.1130/Focus052008.1. [Link]

Einaudi, F., M. Godard, P. Pezard, J. J. Cochemé, C. Coulon, T. Brewer, and P. Harvey, 2003: Magmatic cycles and formation of the upper oceanic crust at spreading centers: geochemical study of a continuous extrusive section in the Oman ophiolite. Geochem. Geophys. Geosyst., 4, doi: 10.1029/2002GC000362. [Link]

Furnes, H., M. de Wit, and Y. Dilek, 2014: Four billion years of ophiolites reveal secular trends in oceanic crust formation. Geoscience Frontiers, 5, 571-603, doi: 10.1016/j.gsf.2014.02.002. [Link]

Herzberg, C. and P. D. Asimow, 2008: Petrology of some oceanic island basalts: PRIMELT2.XLS software for primary magma calculation. Geochem. Geophys. Geosyst., 9, Q09001, doi: 10.1029/2008GC002057. [Link]

Herzberg, C. and P. D. Asimow, 2015: PRIMELT3 MEGA. XLSM software for primary magma calculation: Peridotite primary magma $\mathrm{MgO}$ contents from the liquidus to the solidus. Geochem. Geophys. Geosyst., 16, 563578, doi: 10.1002/2014GC005631. [Link]

Herzberg, C. and E. Gazel, 2009: Petrological evidence for secular cooling in mantle plumes. Nature, 458, 619622, doi: 10.1038/nature07857. [Link]

Herzberg, C. and M. J. O'Hara, 2002: Plume-associated ultramafic magmas of Phanerozoic age. J. Petrol., 43, 1857-1883, doi: 10.1093/petrology/43.10.1857. [Link]

Herzberg, C., P. D. Asimow, N. Arndt, Y. Niu, C. M. Lesher, J. G. Fitton, M. J. Cheadle, and A. D. Saunders, 2007: Temperatures in ambient mantle and plumes: Constraints from basalts, picrites, and komatiites. Geochem. Geophys. Geosyst., 8, Q02006, doi: 10.1029/2006GC001390. [Link]
Hole, M. J., 2015: The generation of continental flood basalts by decompression melting of internally heated mantle. Geology, 43, 311-314, doi: 10.1130/G36442.1. [Link]

Hsieh, R. B. J., J. G. Shellnutt, and M. W. Yeh, 2016: Age and tectonic setting of the East Taiwan ophiolite: implications for the growth and development of the South China Sea. Geol. Mag., 1-15, doi: 10.1017/ S0016756816000054. [Link]

Huang, C. Y., P. B. Yuan, and S. J. Tsao, 2006: Temporal and spatial records of active arc-continent collision in Taiwan: A synthesis. Geol. Soc. Am. Bull., 118, 274288, doi: 10.1130/B25527.1. [Link]

Ichiyama, Y., A. Ishiwatari, and K. Koizumi, 2008: Petrogenesis of greenstones from the Mino-Tamba belt, SW Japan: Evidence for an accreted Permian oceanic plateau. Lithos, 100, 127-146, doi: 10.1016/j.lithos.2007.06.014. [Link]

Ichiyama, Y., A. Ishiwatari, J. I. Kimura, R. Senda, and T. Miyamoto, 2014: Jurassic plume-origin ophiolites in Japan: Accreted fragments of oceanic plateaus. Contrib. Mineral. Petrol., 168, doi: 10.1007/s00410-0141019-1. [Link]

Ishiwatari, A., 1991: Time-space distribution and petrologic diversity of Japanese ophiolites. In: Peters, T., A. Nicolas, R. G. Coleman (Eds.), Ophiolite Genesis and Evolution of the Oceanic Lithosphere, Springer Netherlands, 723-743, doi: 10.1007/978-94-011-33586_37. [Link]

Ishiwatari, A., 1994: Circum-Pacific Phanerozoic multiple ophiolite belts. Circum-Pacific Ophiolites: Proceedings of the $29^{\text {th }}$ International Geological Congress. Part D, VSP Publishers, Netherlands, 7-28.

Jahn, B., 1986: Mid-ocean ridge or marginal basin origin of the East Taiwan Ophiolite: Chemical and isotopic evidence. Contrib. Mineral. Petrol., 92, 194-206, doi: 10.1007/BF00375293. [Link]

Juan, V. C., H. J. Lo, and C. H. Chen, 1976: Crystallizationdifferentiation of Taiwanite. Proc. Geol. Soc. China, 19, 87-97.

Juan, V. C., H. J. Lo, and C. H. Chen, 1980: Genetic relationships and the emplacement of the exotic basic rocks enclosed in the Lichi melange, east Coastal Range, Taiwan. Proc. Geol. Soc. China, 23, 56-68.

Kamenetsky, V. S., J. L. Everard, A. J. Crawford, R. Varne, S. M. Eggins, and R. Lanyon, 2000: Enriched endmember of primitive MORB melts: Petrology and geochemistry of glasses from Macquarie Island (SW Pacific). J. Petrol., 41, 411-430.

Kao, H., S. J. Shen, and K. F. Ma, 1998: Transition from oblique subduction to collision: Earthquakes in the southernmost Ryukyu arc-Taiwan region. J. Geophys. Res., 103, 7211-7229, doi: 10.1029/97JB03510. [Link]

Karson, J. A., D. L. Elthon, and S. E. DeLong, 1983: 
Ultramafic intrusions in the Lewis Hills massif, Bay of Islands ophiolite complex, Newfoundland: Implications for igneous processes at oceanic fracture zones. Geol. Soc. Am. Bull., 94, 15-29, doi: 10.1130/0016-76 06(1983)94<15:UIITLH>2.0.CO;2. [Link]

Kelley, K. A. and E. Cottrell, 2012: The influence of magmatic differentiation on the oxidation state of $\mathrm{Fe}$ in a basaltic arc magma. Earth Planet. Sci. Lett., 329-330, 109-121, doi: 10.1016/j.eps1.2012.02.010. [Link]

Kurth-Velz, M., A. Sassen, and S. J. G. Galer, 2004: Geochemical and isotopic heterogeneities along an island arc-spreading ridge intersection: Evidence from the Lewis Hills, Bay of Islands ophiolite, Newfoundland. J.Petrol., 45, 635-668, doi: 10.1093/petrology/egg096. [Link]

Le Bas, M. J., 2000: IUGS reclassification of the high-Mg and picritic volcanic rocks. J. Petrol., 41, 1467-1470, doi: 10.1093/petrology/41.10.1467. [Link]

Lee, C. T. and Y. Wang, 1987: Paleostress change due to the Pliocene-Quaternary arc-continent collision in Taiwan. Mem. Geol. Soc. China, 9, 63-86.

Lee, T. Y. and L. A. Lawver, 1995: Cenozoic plate reconstruction of Southeast Asia. Tectonophysics, 251, 85138, doi: 10.1016/0040-1951(95)00023-2. [Link]

Li, C. F., X. Xu, J. Lin, Z. Sun, J. Zhu, Y. Yao, X. Zhao, Q. Liu, D. K. Kulhanek, J. Wang, T. Song, J. Zhao, N. Qiu, Y. Guan, Z. Zhou, T. Williams, R. Bao, A. Briais, E. A. Brown, Y. Chen, P. D. Clift, F. S. Colwell, K. A. Dadd, W. Ding, I. H. Almeida, X. L. Huang, S. Hyun, T. Jiang, A. A. P. Koppers, Q. Li, C. Liu, Z. Liu, R. H. Nagai, A. Peleo-Alampay, X. Su, M.L. G. Tejada, H. S. Trinh, Y.C. Yeh, C. Zhang, F. Zhang, and G. L.Zhang, 2014: Ages and magnetic structures of the South China Sea constrained by deep tow magnetic surveys and IODP Expedition 349. Geochem. Geophys. Geosyst., 15, 4958-4983, doi: 10.1002/2014GC005567. [Link]

Liou, J. G., 1979: Zeolite facies metamorphism of basaltic rocks from the East Taiwan Ophiolite. Am. Mineral., 64, 1-14.

Liou, J. G. and W. G. Ernst, 1979: Oceanic ridge metamorphism of the East Taiwan Ophiolite. Contrib. Mineral. Petrol., 68, 335-348, doi: 10.1007/BF00371555. [Link]

Liou, J. G., C. Y. Lan, J. Suppe, and W. G. Ernst, 1977: The East Taiwan Ophiolite: Its occurrence, petrology, metamorphism, and tectonic setting. Mining Research and Service Organization, Special Report No. 1, 212 pp.

MacLeod, C. J., C. J. Lissenberg, and L. E. Bibby, 2013: "Moist MORB" axial magmatism in the Oman ophiolite: The evidence against a mid-ocean ridge origin. Geology, 41, 459-462, doi: 10.1130/G33904.1. [Link]

Nicolas, A., 1989: Structures of Ophiolites and Dynamics of Oceanic Lithosphere, Springer Netherlands, 370 pp, doi: 10.1007/978-94-009-2374-4. [Link]
Page, B. M. and J. Suppe, 1981: The Pliocene Lichi melange of Taiwan: Its plate-tectonic and olistostromal origin. Am. J. Sci., 281, 193-227, doi: 10.2475/ajs.281.3.193. [Link]

Pearce, J. A., S. J. Lippard, and S. Roberts, 1984: Characteristics and tectonic significance of supra-subduction zone ophiolites. Geol. Soc. Lond. Spec. Publ., 16, 7794, doi: 10.1144/GSL.SP.1984.016.01.06. [Link]

Penrose, C. P., 1972: Penrose field conference on ophiolites. Geotimes, 17, 24-25.

Peters, T. and I. Mercolli, 1998: Extremely thin oceanic crust in the Proto-Indian Ocean: Evidence from the Masirah Ophiolite, Sultanate of Oman. J. Geophys. Res., 103, 677-689, doi: 10.1029/97JB02674. [Link]

Searle, M. and J. Cox, 1999: Tectonic setting, origin, and obduction of the Oman ophiolite. Geol. Soc. Am. Bull., 111, 104-122, doi: 10.1130/0016-7606(1999)111<010 4:TSOAOO $>2.3 . \mathrm{CO} ; 2$. [Link]

Shao, W. Y., 2015: Zircon U-Pb and Hf isotope constraints on the petrogenesis of igneous rocks in eastern Taiwan. Ph.D. Thesis, National Taiwan University, 287 pp.

Stern, R. J. and S. H. Bloomer, 1992: Subduction zone infancy: Examples from the Eocene Izu-Bonin-Mariana and Jurassic California arcs. Geol.Soc. Am. Bull., 104, 1621-1636, doi: 10.1130/0016-7606(1992)104<1621: SZIEFT>2.3.CO;2. [Link]

Suppe, J., 1984: Kinematics of arc-continent collision, flipping of subduction, and back-arc spreading near Taiwan. Mem. Geol. Soc. China, 6, 21-33.

Suppe, J. and J. G. Liou, 1979: Tectonics of the Lichi Melange and East Taiwan ophiolite. Mem. Geol. Soc. China, 3, 147-153.

Suppe, J., J. G. Liou, and W. G. Ernst, 1981: Paleogeographic origins of the Miocene East Taiwan Ophiolite. Am. J. Sci., 281, 228-246, doi: 10.2475/ajs.281.3.228. [Link]

Taylor, B. and D. E. Hayes, 1980: The tectonic evolution of the South China Basin. In: Hayes, D. E. (Ed.), The Tectonic and Geologic Evolution of Southeast Asian Seas and Islands, American Geophysical Union, Washington, D. C., 89-104, doi: 10.1029/GM023p0089. [Link]

Taylor, B. and D. E. Hayes, 1983: Origin and history of the South China Sea basin. In: Hayes, D. E. (Ed.), The Tectonic and Geologic Evolution of Southeast Asian Seas and Islands: Part 2, American Geophysical Union, Washington D.C., 23-56, doi: 10.1029/GM027p0023. [Link]

Teng, L. S., 1990: Geotectonic evolution of late Cenozoic arc-continent collision in Taiwan. Tectonophysics, 183, 57-76, doi: 10.1016/0040-1951(90)90188-E. [Link]

Teng, L. S., 1996: Extensional collapse of the northern Taiwan mountain belt. Geology, 24, 949-952, doi: 10.11 30/0091-7613(1996)024<0949:ECOTNT>2.3.CO;2. [Link] 
Teng, L. S., 2007: Quaternary Tectonics of Taiwan. Spec. Publ. Cent. Geol. Surv., 18, 1-24.

Thy, P. and C. Xenophontos, 1991: Crystallization orders and phase chemistry of glassy lavas from the pillow sequences, Troodos Ophiolite, Cyprus. J. Petrol., 32, 403-428, doi: 10.1093/petrology/32.2.403. [Link]

Tsai, Y. B., 1986: Seismotectonics of Taiwan. Tectonophysics, 125, 17-37, doi: 10.1016/0040-1951(86)90005-3. [Link]
Whattam, S. A. and R. J. Stern, 2011: The 'subduction initiation rule': A key for linking ophiolites, intra-oceanic forearcs, and subduction initiation. Contrib. Mineral. Petrol., 162, 1031-1045, doi: 10.1007/s00410-0110638-z. [Link]

Yui, T. F. and M. H. Yang, 1988: Trace element implication of the paleo-tectonic environment of pillow basalts from the East Taiwan ophiolite. Proc. Geol. Soc. China, 31, 11-23. 